\title{
Hematopoietic Stem Cell Transplantation Based on the Transdisciplinary Care
}

Isabelle Campos de Azevedo ${ }^{1}$, Rejane Maria Paiva de Menezes ${ }^{1}$, Soraya Maria de Medeiros ${ }^{1}$, Diana Paula de Souza Rego Pinto Carvalho', Giovanna Karinny Pereira Cruz ${ }^{1}$, Priscila Fernandes Meireles Câmara', Rita de Cássia Lira da Silva', Aline Aires de Oliveira', Jéssica Valeska Herculano Lima ${ }^{1}$, Luísa Alves Pereira de Aquino ${ }^{1}$, Marcos Antonio Ferreira Júnior ${ }^{1}$

\section{Abstract}

Objetive: Discuss the importance of multidisciplinary care for patients undergoing Hematopoietic Stem Cell Transplantation (HSCT) based on the transdisciplinary care.

Method: This is a theoretical essay discussing.

Results: Each year, about 50 million people are undergoing HSCT worldwide. This therapeutic strategy is used for some oncological, hematological or immunological, malignant and non-malignant inherited or acquired diseases. During the steps after HSCT, patients, and their families experience moments of anxiety, anguish and uncertainty that cause stress and interfere with their daily lives. The multidisciplinary team working in HSCT service provide complex and specialized care since this scenario requires specific knowledge of the area. However, they do not relieve the interweaving of new knowledge for an interdisciplinary practice that meets the patient's health needs in this delicate moment of his life. From this perspective, health professionals of HSCT service should excel by constantly learning and dynamic interventions and sharing of knowledge in the multidisciplinary team that includes a complex and transdisciplinary care.

Conclusion: This essay causes the discussion about care in HSCT based on transdisciplinary care. It should be emphasized the responsibility of each member of the multidisciplinary team for the contribution and strengthening of the patient's quality of life. In a way, the interdisciplinary care permeates the complexity in an open perspective of approximation of the various areas of knowledge.
1 Universidade Federal do Rio Grande do Norte, Natal/RN, Brasil.

Contact information:

Isabelle Campos de Azevedo.

Address: 4 Universidade Federal do Rio Grande do Norte, Centro de Ciências da Saúde, Departamento de Enfermagem. Avenida Salgado Filho, S/N, Lagoa Nova, Natal, RN, Brasil. CEP: 59078970.

झ isabellebr2511@gmail.com

Keywords

Nursing; Hematopoietic Stem Cell Transplantation; Patient Care Planning; Health Personnel; Patient-Centered Care. 


\section{Introduction}

About 50 thousand people are submitted to Hematopoietic Stem Cell Transplant (HSCT) worldwide each year [1]. This procedure consists of a therapeutic strategy for some oncological, hematological or immunological, malignant and non-malignant inherited or acquired diseases [2]. It is an intravenous infusion of sound hematopoietic progenitor cells $(\mathrm{HPC})$, extracted from the bone marrow, from the peripheral blood, umbilical or placental cord to fix the spinal cord and immune function of patients with possible cure or increased of the disease-free survival [3].

Despite the HSCT be successfully used, morbidity and mortality rates related to the procedure in its various stages are perceived. Such occurrences may occur from the pre-transplant period in which it is held by the multidisciplinary team evaluation and admission of the patient in protective isolation in HSCT sector. Then, there is the conditioning regimen when the patient receives high-dose of chemotherapy, followed by aspiration, processing and HPC infusion. After that, the patient undergoes bone marrow graft, a moment of the implementation of the cord that ends in the hospital and outpatient follow-up, when the grafting is considered successful. In the post-transplantation recovery, the risk of complications increases with the possibility of the development of Graft-versus-Host Disease (GVHD). [3]

GVHD may present dermatological, gastrointestinal, ophthalmology and respiratory morbidities, among others. These conditions require attention and special care by the nursing staff, other health professionals, the patients and their family/caregivers. These morbidities may impair the quality of life and contribute to the mortality of transplanted patients [1-4].

During the steps after HSCT, patients, and their families experience moments of anxiety, anguish and uncertainties that could cause stress and interfere with their daily lives. Hospital discharge influences the imagination of those involved in a special way with the patient, as they will need to readjust to their daily routine and the possibility of recurrence of the disease and the onset of complications related to drug toxicity or even the GVHD [5].

In this context, the multidisciplinary health team of HSCT service plays an important role in planning actions for guidance and training of family/caregivers for patient-centered care, and the implementation of interventions always in a transdisciplinary perspective that both assist or improve their quality of life, as considering the context in which the patient is inserted [6].

The transdisciplinary approach goes beyond the care guided by techniques and protocols. It presupposes a shared comprehensive care with a tendency to interdisciplinary relationships horizontally, able to patients and families to be autonomous and to perform efficient self-care.

This understanding requires teamwork between professionals and professionals and professionals and patients. Efficient care cannot be achieved if there is no collaboration between those that offer and who receives it. In this sense, the work of the nurse as a member of the multidisciplinary team and health sector manager stands out from the systematization of actions to the patient and staff, as well as the possibility of bond formation between professionals and patients. This is possible because the nurses have the skills necessary for the establishment of a bond, considering that the nursing staff works in an integrated way in interaction and dialogue with the various actors and sectors of health services.

The choice of the topic of disciplinary care provided during HSCT occurs due to the emergence of this kind of assistance in the field and the importance of sharing and knowledge socialization from the perspective of health patient-centered care in reciprocal movements and not only in parallel. From this perspective, this study discusses 
the importance of care for patients undergoing Hematopoietic Stem Cell Transplantation based on transdisciplinary care.

\section{Method}

This is a theoretical essay discussing, from the look of different authors, the care/caring of the multidisciplinary team, its prospects and the influence of prevailing paradigms and emerging with a focus on interdisciplinary care. A research of the literature was performed in electronic databases (Latin American and Caribbean Health Sciences (LILACS); Scientific Electronic Library Online (ScieLO); National Library of Medicine (PubMed) and SCOPUS) and books. As inclusion criteria, classic and updated studies on the subject were selected.

This article will surely bring contributions to provide subsidies for the reflection of professionals about the care/caring to reveal new ways to approach the relationship between nursing practice and the dominant paradigms and emerging health.

\section{Results}

The results were divided into two themes, the first deals with the concepts that will be covered throughout the text and the second discusses the interdisciplinary care in HSCT.

\section{Conceptions Supporting the Transdisciplinary Care}

It is worth noting the importance of the discussion of the concepts that will be used and that permeate the building and read in this essay.

The first concept is the paradigm that means the set of beliefs, values, and techniques shared by members of a given society. Kuhn applies this concept to the Disciplinary Matrix expression. He explains that the term Disciplinary refers to the common empowerment to participants in a particular discipline. Thus, a paradigm is characterized as a model that guides the study, research, and attitudes of a scientific community that seeks practical solutions to address the problems of various areas of knowledge [7].

The concept of discipline involves a scientific body of knowledge organized in common to its practitioners, with specific methods and practices, which brings together knowledge about a particular object to facilitate the teaching-learning process [7]. The discipline has a focus of specific study, which somehow favored the expertise and the production of research and reductionist studies. However, many times in the history of humanity and some areas of knowledge, this fragmentation has been and is still required to provide scientific and technological development [8].

The term transdisciplinary indicates that knowledge is at once between the disciplines, across disciplines, and beyond all discipline, but also considers the human subjectivity as a producer of knowledge. [9] The transdisciplinary practice consider the experience with diversity while linking various disciplines to describe, observe, understand and intervene in reality, when moving from a part to the whole or the whole to a part, without exceeding the disciplines and without using a reductionist focus [10].

Morin discusses this practice when he speaks of the holographic principle, in which not only the part is on the whole, but also the whole is in its parts. He cites an example from the biological world in which every cell in the human body contains all the genetic information of the organism. It ends with the assertion that the hologram idea goes beyond reductionism that sees only the parts or the holism that only sees the whole. This way of looking at the world with new ideas, visions, discoveries and reflections results in the complex paradigm [11].

Complexity is the web of events, actions, interactions, retroactions, determinants and chances to build up the phenomenal world, a heterogeneous construct that associates the one and the many, the local and the global, the subject and the object [11]. 
The complex thinking goes against reductionism by the Cartesian paradigm since it means to access, coordinate and organize the multiple relationships between the parties, the whole and the context to enable a multidisciplinary, contextual, dynamic and interdisciplinary approach to reality [10].

Finally, the concept of multidisciplinary team. In the health field, a team is characterized as multidisciplinary when it acts together with professionals in different areas with a common goal, the restructuring of the work process in health services to changes in the ways of acting on the health-disease process [12]. This proposal has been adopted as a coping strategy of hyper-specialization and fragmentation of care process, reflecting upright and rigid aspects, without considering the individual needs [13].

The multi-professionality happens when a practical problem is solved by the interaction of the expertise of professionals from different areas. It should be noted that this should be a collaborative share, a practice in which the scientific and technical knowledge are interconnected, like a web, which complements each other in a reciprocal movement and not parallel [14].

\section{Care Based on the Transdisciplinarity and Hsct}

When anchoring their assumptions based on the transdisciplinary care, the multidisciplinary team search for the integration of knowledge from all disciplines that make up their corpus and also recognizes the importance of human subjectivity in the production of this knowledge [10]. The current goal of the health paradigm is to unite the different disciplines in a strategic movement around the human being to unify their relationship with the environment, biological, psychological, cultural and religious values, to constitute a disciplinary care addressing the complexity inherent to their health $[15,16]$.

The indication for the HSCT is associated with situations of pain, suffering and fear by the patients to become dependent, losing their functions and because of the isolation during hospitalization. Also, with the disease and long-term treatment, there is some disruption in their family relationships, their jobs, in their life context, due to their poor health condition, the immunosuppression and transplant process [3].

In this context, it becomes easier the patients lie in a derogatory way of life in which their subjective needs can take an impoverished and immersive dimension to reduce drastically their quality of life. Helping them overcome this perspective that dominates the imaginary deteriorates subjectivity and closes the existential horizons as a major challenge for the multidisciplinary team providing care during all stages of HSCT [17].

Professionals are working in HSCT service also relieve complex and specialized care [18], given that this scenario requires specific knowledge of the area. However, they do not relieve the interweaving of new knowledge for an interdisciplinary practice that meets the patient's health needs in this delicate moment of their lives.

The practice of multidisciplinary team of HSCT service should consider the patient in his singularity and the effects that transplantation brings to his quality of life, but also in his family context. Support psychological and basic health care strategies can help mitigate the impact generated by the situations experienced to enhance the bond between familypatient-professional and professional-professional, as a potentiate instrument of more effective coping process [17].

Therefore, it is necessary that the multidisciplinary team, responsible for the systematization and assistance in HSCT service, understand the dynamics involved in the professional-patient-family-care relationship and identify the influence of psychosocial and health-disease factors exercise in that context, to facilitate the process of adaptation to the new reality. [19]

Given the high level of complexity that permeates the HSCT, it is clear the importance of a multidisci- 
plinary team specialized and trained for the development of such a complex procedure and disciplinary care. Under the HSCT, there is no room for guided activities and care in the Cartesian paradigm, which organizes the conventional science into autonomous and watertight disciplines. This paradigm tends to be replaced by new models of know-how in health, with disciplines organized as a network of knowledge, with common objectives that complement each other.

The health care in HSCT brings different meanings and approaches with values, beliefs and attitudes inherent to the patients that require appropriate and individualized interventions to minimize the harm to their physical and mental integrity. Such care needs put the multidisciplinary team to confront the interference of feelings and subjectivities that bring to everyday practice, based on scientific knowledge, but they often become professional performance [20].

It is known that knowledge began its long journey outside the walls of the school in the attempt to bring theory and practice. From the complex thinking and the need for a new paradigm, caring goes from a simple verbal meaning to emerge from the conception of the human being in an open system while involved in a web, with the opportunity for an integrated action that includes different dimensions and experiences.

Promoting health is to know how to deal with diversity. From this perspective, health professionals of HSCT service should excel by constantly learning and dynamic interventions that address care being complex and transdisciplinary at the same time.

\section{Conclusion}

This essay causes the discussion about care in HSCT based on transdisciplinary care. It should be emphasized the responsibility of each member of the multidisciplinary team for the contribution and strengthening of the patient's quality of life. In a way, the interdisciplinary care permeates the complexity in an open perspective of approximation of the various areas of knowledge.

In this context, it is emphasized the inclusion of nurses in the multidisciplinary team, highlighting the importance of their role in the perspective of this conception of knowledge network, in articulated movements with other professionals on a reciprocal and not parallel basis.

It is evident there is still much to be done about the subjects which are part of the multidisciplinary team and their object of work, for the development of interdisciplinary care strategies grounded in the complex paradigm. It is considered that this discussion should be a mandatory approach to professionals who work with HSCT. However, studies that focus on the care provided to patients undergoing HSCT with research methodologies that guarantee results and implications for positive changes of practice in health are necessary.

\section{Acknowledgment}

To the Coordination of Higher Education Personnel (CAPES; masters scholarship).

\section{References}

1. Majhail NS, Bajorunaite R, Lazarus HM, Wang Z, Klein JP, Zhang MJ et al. Long-term survival and late relapse in 2-year survivors of autologous haematopoietic cell transplantation for Hodgkin and non-Hodgkin lymphoma. Br J Haematol. 2009; 147: 12939.

2. Ljungman $P$, Bregni $M$, Brune $M$, Cornelissen J, de Witte $T$, Dini $G$ et al. Allogeneic and autologous transplantation for haematological diseases, solid tumours and imune disorders: current practice in Europe 2009. Bone Marrow Transplant. 2010; 45(2): 219-34.

3. Santos CLT, Sawada NO, Santos JLF. Avaliação da qualidade de vida relacionada à saúde de pacientes submetidos ao transplante de células-tronco hematopoéticas. Rev. Latino-Am. Enfermagem. 2011; 19(6). 
4. Wingard JR, Majhail NS, Brazauskas R, Wang Z, Sobocinski KA, Jacobsohn $D$, et al. Long-term survival and late deaths after allogeneic hematopoietic cell transplantation. J Clin Oncol. 2011; 29: 2230-9.

5. Costanzo ES, Juckett MB, Coe CL. Biobehavioral influences on recovery following hematopoietic stem cell transplantation. Brain Behav Immun. 2013; 30: 68-70.

6. Lima K, Bernardino E. O cuidado de enfermagem em unidade de transplante de células-tronco hematopoéticas. Texto Contexto Enferm. 2014; 23(4): 845-53.

7. Kuhn TS. A estrutura das revoluções científicas. Tradução: Boeira BV, Boeira N. São Paulo: Perspectiva; 2001.

8. Teixeira ER, Barbosa MS, Silva CMC. Trabalhando a transdisciplinaridade na clínica do cuidado em saúde. Rev. Enf. Profissional. 2014; 1(2): 315-30

9. Nicolescu B. O manifesto da transdisciplinaridade. Tradução: Souza LP. $3^{\text {a }}$ ed. São Paulo: TRIOM; 2005.

10. Feriotti ML. Equipe multiprofissional, transdisciplinaridade e saúde: desafio do nosso tempo. Vínculo - Revista do NESME. 2009; 2(6): 179-94

11. Morin E. Introdução ao pensamento complexo. Tradução: Lisboa E. Porto Alegre: Sulina; 2006.

12. Costa RKS, Enders BC, Menezes RMP. Trabalho em equipe de saúde: uma análise contextual. Cienc Cuid Saude. 2008; 7(4): 530-6.

13. Peduzzi, M. Equipe multiprofissional de saúde: conceito e tipologia. Rev Saúde Pública, 2001; 35(1): 103-9.

14. Minayo, MCS. Da inteligência parcial ao pensamento complexo: desafios da ciência e da sociedade contemporânea. Política \& Sociedade. 2011; 10(19): 41-56.

15. Almeida Filho $\mathrm{N}$. Intersetorialidade, transdisciplinaridade e saúde coletiva: atualizando um debate em aberto. RAP. 2000; 34(6): 11-34.

16. Villermay D. Rumo a um modelo transdisciplinar da saúde. Centro de Educação Transdisciplinar; 2005.
17. Alves RP, Oliveira-Cardoso E, Mastropietro AP, Voltarelli JC, Santos MA. Transplante de células-tronco hematopoéticas e qualidade de vida após alta hospitalar. Psic., Saúde \& Doenças. 2012; 13(1): 87-99.

18. Zavadil ETC, Mantovani MF, Cruz EDA. Representação do enfermeiro sobre infecções em pacientes submetidos a transplante de células-tronco hematopoiéticas. Esc Anna Nery. 2012; 16(3): 583-7.

19. Matias AB, Oliveira-Cardoso EA, Mastropietro AP, Voltarelli JC, Santos MA. Qualidade de vida e transplante de células-tronco hematopoéticas alogênico: um estudo longitudinal. Estud. psicol. 2011; 28(2): 187-97.

20. Silva RCV, Cruz EA. Planejamento da assistência de enfermagem ao paciente com câncer: reflexão teórica sobre as dimensões sociais. Esc Anna Nery. 2011; 15(1): 180-5.
Publish in International Archives of Medicine

International Archives of Medicine is an open access journal publishing articles encompassing all aspects of medical science and clinical practice. IAM is considered a megajournal with independent sections on all areas of medicine. IAM is a really international journal with authors and board members from all around the world. The journal is widely indexed and classified Q1 in category Medicine. 